仙台での第 62 回日本脳神経外科学会総会が終了し, 日本脳神経外科コングレスの親組織である日本脳神経外 科学会が新たな時代を迎えました. 本総会で日本脳神経 外科学会が解散し, 社団法人化に向けた具体的な事務手 続きを開始しました。本年 11 月末には文部科学省から 正式に認可され, 社団法人日本脳神経外科学会が発足し ます。昭和 39 年に脳神経外科が, 診療科として認可さ れたことに匹敵する社会的認知といえます。吉本高志先 生, 桐野高明先生, 小川 彰先生, 寺本 明先生等, 法 人化にご尽力された先生方に感謝致します。

文科系の事物に比較して, 理科系, 特に医学, なかで も脳神経外科医は社会的活動をたくさん施行しているに もかかわらず，社会的認知度や評価が低いといえます。 そのことは, 脳死判定に関する種々の問題で救急医学会 と比較してみれば理解できます。現代は, 溢れるばかり の情報があり，その中身も種々の価值観で構成されてい ます。私たち脳神経外科医の学問, 教育, 臨床での活動 が社会から正当性を得ることが大切です．社会から正当 性を得るためには, 私たちの活動内容を, 社会に向けて 平易な言葉で分かりやすく説明し, 社会から共感を得な ければなりません，共感を得て，はじめて正当性が得ら れます. 今回の社団法人化で, 年次学術総会の会計が法 人と一括会計になる等，新たな越さねばならない問題が 出てくると思います。しかし, 発展的な問題であると思 います。社団法人化は, 日本脳神経外科コングレス会員 のみならず, 日本脳神経外科学会全員の社会的認知度の 貢献になると思います，無認可団体が公的，国家的認知 団体になったのです。団体として, 社員としての責任も
でてきますが，社会に公的にいろいろな事物を発言でき ることになったのです，向後の活動には，日本脳神経外 科コングレスとしても, 社団法人日本脳神経外科学会を 全面的に応援することになると思います。

\section{* *}

本号では，2編の原著が掲載されています，宇野昌明 先生の『冠動脈疾患合併例に対する CEA』は, 徳島大学の 長年にわたる CEA を解析し, 冠動脈疾患合併例におけ る心合併症の発生率と予防法を展望も含め解説していま す。近年日本における CEA の手術件数は増加しており, 時宜に叶った素晴らしい論文です，また，原田薰雄先生 の『高龄脳血管障害患者における経皮内視鏡的胃瘦造設 術の有用性』は, 脳神経外科領域の大切な分野である脳卒 中後の管理の分野で，大変貢献する論文です．本論文の 内容は, 従来あまり脳神経外科学会の領域では扱われな かった分野ですが，現場では重要な問題であり，現実の 脳神経外科分野の問題を取り上げた点で良いと思いま す. 症例報告は 3 編です。渡邊陽祐先生, 永田安徳先生, 島田健司先生の論文は共に同様な症例を経験した場合, 貢献できる論文です。

日本脳神経外科コングレスも新たな運営委員に衣替え をしました，永廣信治会長の元，来年度の素晴らしい学 会を期待します。また，橋本信夫編集長がいろいろな工 夫をし，機関誌の発展を図っています。会員の協力を熱 望します。

(嘉山孝正)

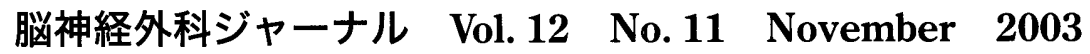
2003 年 11 月 20 日発行
年ぎめ予約購読料 24,469 円 送料弊社負担
編集・発行／日本脳神経外科コングレス
T113-8421 東京都文京区本郷 2-1-1 順天堂大学医学部 脳神経外科教室内
○ 03-3813-1039 FAX 03-5684-3096

定価 1 部 2,039 円（本体 1,942 円） 送料 85 円

\author{
発売/侏)三輪書店 \\ 発売人 佐々木憲一郎 \\ テ113-0033 東京都文京区本郷 6-17-9 本郷綱ビル \\ TEL $03-3816-7796$ FAX $03-3816-8762$ \\ 郵便振替 $001810-0-255208$ \\ 印刷所／三報社印刷㑣）TEL 03-3637-0005 広告申込所／㤦ハイブリッジエージェンシー TEL 03-3814-0089
}

本誌の内容の無断複写・複製・転載は, 著作権・出版権の侵害となることがありますのでご注意ください. 